\title{
Synthesis, Antibacterial and Antifungal Evlaution of Novel Pyrazoline Derivatives
}

\author{
B.C. Revanasiddappa, M.S. J isha, M.Vijay Kumar and Hemanth Kumar
}

Department of Pharmaceutical Chemistry, NGSM Institute of Pharmaceutical

Sciences of Nitte -Deemed to be University, Paneer, Deralakatte

Mangalore-575 018, Karnataka, India

(Received: August 13, 2018; Accepted: October 7, 2018; Published (web): December 10, 2018)

\begin{abstract}
A new series of chalcones (2a-j) were prepared by reacting substituted aldehydes and substituted ketones in alcohol medium in presence of $\mathrm{NaOH}$. The chalcones underwent selective cyclization with guanicol hydrazide (1) in glacial acetic acid medium to yield the title compounds 1,3,5-trisubstituted pyrazolines (3a-j). The new compounds were characterized on the basis of ${ }^{1} \mathrm{H}-\mathrm{NMR}$, IR and mass spectral data. All the newly synthesized compounds were evaluated for their in-vitro antibacterial and antifungal activities. Some of the tested compounds $\mathbf{3 a}$ and 3e showed good activity against bacterial strains and compounds $\mathbf{3 d}$ and $\mathbf{3 h}$ revealed good activity against fungal strains.
\end{abstract}

Key words: Chalcones, pyrazolines, antibacterial activity, antifungal activity, guanicol hydrazide

\section{INTRODUCTION}

Heterocyclic compounds are extremely significant to life and are present in living cells in different forms. These compounds serve as the starting materials for the manufacture of variety of a drugs. Heteroatoms commonly present in these compounds are oxygen, nitrogen, sulphur like simple carbocyclic compounds. Heterocyclic compounds are abundantly available in nature.

Pyrazoline is a five-membered heterocyclic compound having two adjacent nitrogen atoms within the ring. It has only one endocyclic double bond and is basic in nature. The dihydro derivative of pyrazole is known as pyrazoline. Depending on the position of the double bond, it can exist in three separate forms: 1-pyrazoline, 2pyrazoline and 3-pyrazoline. ${ }^{1}$

Pyrazolines display a broad spectrum of potential pharmacological activities and are present in a number of pharmacologically active molecules such

Correspondence to: B.C. Revanasiddappa

Email: revan@nitte.edu.in

Dhaka Univ. J. Pharm. Sci. 17(2): 221-226, 2018 (December)

DOI: http://dx.doi.org/10.3329/dujps.v17i2.39179 as phenazone/ amidopyrene/methampyrone (analgesic and antipyretic), azolid/tandearil (antiinflammatory), indoxacarb (insecticide) and anturane (uricosuric). Changes in their structure have offered a high degree of diversity that has proven useful for the development of new therapeutic agents having improved potency and lesser toxicity.

Chalcones are 1,3-diphenyl-2-propene-1-one, in which two aromatic rings are linked by a three carbon $\alpha, \beta$-unsaturated carbonyl system. These are abundant in edible plants and are considered to be the precursors of flavonoids and isoflavonoids. ${ }^{2}$ Chalcones are synthesized by Claisen-Schmidt condensation of aldehydes and ketones by base catalyzed or acid catalyzed followed by dehydration to yield chalcones. ${ }^{3}$

Chalcones are popular intermediates for synthesizing various heterocyclic compounds. The compounds with the backbone of chalcones have been reported to possess various biological activities such as antimicrobial ${ }^{4}$, anti-inflammatory ${ }^{5}$, antimalarial $^{6}$, molluscicidal ${ }^{7}$, anti-mycobacterail ${ }^{8}$ etc. Similarly pyrazolines are reported to possess 
antimicrobial $^{9}$, anti-inflammatory ${ }^{10}$, anti-tubercular ${ }^{11}$, antibacterial $^{12}$, antidepressant ${ }^{13}$, etc prepertes.

With this in mind and in continuation of our work on pyrazolines ${ }^{14-17}$, we envisage the design and synthesis of a combination of guanicol hydrazide with heterocyclic moiety like pyrazoline, to obtain therapeutically active antibacterial and antifungal agents.

\section{MATERIALS AND METHODS}

Laboratory grade chemicals and reagents were used to synthesize all the reported compounds. The IR spectra were recorded by using Bruker IR spectrometer using a thin film on $\mathrm{KBr}$ pellet technique and frequencies are expressed in $\mathrm{cm}^{-1}{ }^{1} \mathrm{H}-$ NMR spectra were recorded on Bruker Avance-II $400 \mathrm{MHz}$ NMR spectrometer. All spectra were obtained in $\mathrm{CDCl}_{3}$ and DMSO. Chemical shift values are reported in ppm relative to TMS $(\delta=0)$ as internal standard. Mass spectra were recorded on ESI. Melting points were determined by open capillary method and are uncorrected. Precoated silica gel plates (Merck, Silica gel $60 \mathrm{~F}_{254}$ ) were used for analytical TLC and visualized by exposure to iodine vapor and UV radiations. ethyl acetate : acetone (1:9) was as mobile phase.

Synthesis of guanicol hydrazide ${ }^{18}$ (1). To a solution of guanicol ethyl ester $(0.01 \mathrm{~mol})$ in ethanol $(25 \mathrm{ml})$, hydrazine hydrate $(0.02 \mathrm{ml})$ was added and refluxed for about $24 \mathrm{~h}$. The reaction mixture was allowed to cool. The white crystals which are separated, were filtered, dried and recrystallized from ethanol.

$\%$ Yield: $65 \%$, mp: $62-64^{\circ} \mathrm{C}$.

IR $(\mathrm{KBr}) v\left(\mathrm{~cm}^{-1}\right): 1536(\mathrm{C}=\mathrm{C}), 1662(\mathrm{C}=\mathrm{O}), 2837$ $\left(\mathrm{OCH}_{2}\right), 3069(\mathrm{C}-\mathrm{H}), 3327(\mathrm{NH}) .{ }^{1} \mathrm{H}-\mathrm{NMR}\left(\mathrm{CDCl}_{3}\right)$ : $\delta 3.88\left(\mathrm{~s}, \mathrm{OCH}_{3}, 3 \mathrm{H}\right), 3.94$ (bs, $\left.\mathrm{NH}_{2}, 2 \mathrm{H}\right), 4.61$ (s, $\left.\mathrm{OCH}_{2}, 2 \mathrm{H}\right), 6.84-7.04(\mathrm{~m}, \mathrm{Ar}-\mathrm{H}, 4 \mathrm{H}), 8.28$ (s, $\mathrm{CONH}, 1 \mathrm{H})$.

General procedure for the synthesis of chalcones (2a-j). To a solution of substituted aromatic aldehydes $(0.01 \mathrm{~mol})$ and substituted ketones $(0.01 \mathrm{~mol})$ in ethanol $(25 \mathrm{ml})$, a solution of $\mathrm{NaOH}(6 \mathrm{ml}, 40 \%)$ was added. The reaction mixture was stirred at room temp for a period of $24 \mathrm{hr}$, diluted with water $(100 \mathrm{ml})$ and acidified with dil. $\mathrm{HCl}$. The product obtained was filtered, washed with water, dried and recrystallized from ethanol. The physical properties of compounds (2a-j) are given in Table 1.

Table 1. Physical properties of chalcones (2a-j).

\begin{tabular}{lllll}
\hline Compd. & $\mathrm{Ar}^{1}-\mathrm{COCH}_{3}$ & Molecular formula & MP $\left({ }^{\circ} \mathrm{C}\right)$ & Yield (\%) \\
\hline 3a & & & & \\
3b & & & & \\
\end{tabular}


General procedure for the synthesis of 1,3,5trisubstituted pyrazolines (3a-j). A solution of chalcones (2a-j) $(0.01 \mathrm{~mol})$ and guanicol hydrazide (1) $(0.01 \mathrm{~mol})$ in glacial acetic acid $(25 \mathrm{ml})$ was refluxed for about 30-40 hrs. Excess of solvent was removed under reduced pressure and the reaction mixture was poured into ice cold water. The product which was obtained eas filtered, washed with water, dried and recrystallized from ethanol. The physical properties of compounds (3a-j) are given in table 2 .

Table-2. Physical properties of pyrazolines (3a-j).

\begin{tabular}{|c|c|c|c|c|c|}
\hline Compd. & $\mathrm{Ar}-\mathrm{CHO}$ & $\mathrm{Ar}^{1}-\mathrm{COCH}_{3}$ & Molecular formula & $\operatorname{MP}\left({ }^{\circ} \mathrm{C}\right)$ & Yield (\%) \\
\hline 3a & & $4-\mathrm{Cl}$ & $\mathrm{C}_{22} \mathrm{H}_{19} \mathrm{ClN}_{2} \mathrm{O}_{3} \mathrm{~S}$ & $76-78$ & 62 \\
\hline $3 \mathbf{b}$ & & $4-\mathrm{OH}$ & $\mathrm{C}_{22} \mathrm{H}_{20} \mathrm{~N}_{2} \mathrm{O}_{4} \mathrm{~S}$ & $86-88$ & 58 \\
\hline $3 c$ & & $4-\mathrm{Br}$ & $\mathrm{C}_{22} \mathrm{H}_{19} \mathrm{BrN}_{2} \mathrm{O}_{3} \mathrm{~S}$ & $100-02$ & 62 \\
\hline 3d & & $4-\mathrm{OCH}_{3}$ & $\mathrm{C}_{23} \mathrm{H}_{22} \mathrm{~N}_{2} \mathrm{O}_{4} \mathrm{~S}$ & $92-94$ & 66 \\
\hline $3 e$ & $4-\mathrm{CH}_{3}$ & $\mathrm{C}_{6} \mathrm{H}_{5}$ & $\mathrm{C}_{25} \mathrm{H}_{24} \mathrm{~N}_{2} \mathrm{O}_{3}$ & $145-47$ & 63 \\
\hline $3 \mathrm{f}$ & $4-\mathrm{Cl}$ & $\mathrm{C}_{6} \mathrm{H}_{5}$ & $\mathrm{C}_{24} \mathrm{H}_{21} \mathrm{ClN}_{2} \mathrm{O}_{3}$ & $164-66$ & 65 \\
\hline $3 \mathrm{~g}$ & $4-\mathrm{CH}_{3}$ & $4-\mathrm{Cl}$ & $\mathrm{C}_{22} \mathrm{H}_{17} \mathrm{ClN}_{2} \mathrm{O}_{3}$ & $151-53$ & 67 \\
\hline $3 \mathbf{h}$ & $4-\mathrm{OCH}_{3}$ & 2-OH & $\mathrm{C}_{25} \mathrm{H}_{24} \mathrm{~N}_{2} \mathrm{O}_{5}$ & $122-24$ & 61 \\
\hline $3 \mathbf{i}$ & $4-\mathrm{CH}_{3}$ & $2-\mathrm{OH}$ & $\mathrm{C}_{22} \mathrm{H}_{24} \mathrm{~N}_{2} \mathrm{O}_{4}$ & $115-17$ & 62 \\
\hline $3 \mathbf{j}$ & 4-Cl & 2-OH & $\mathrm{C}_{24} \mathrm{H}_{21} \mathrm{ClN}_{2} \mathrm{O}_{4}$ & $132-34$ & 63 \\
\hline
\end{tabular}

5-(4-chlorophenyl)-1-(3-methoxyphenoxy)-3(thiophen-2-yl)-4,5-dihydro-1H pyrazole (3a): IR $(\mathrm{KBr}) v\left(\mathrm{~cm}^{-1}\right): 756(\mathrm{Cl}), 1563(\mathrm{C}=\mathrm{C}), 1585(\mathrm{C}=\mathrm{N})$, $1683(\mathrm{C}=\mathrm{O}), 2881\left(\mathrm{OCH}_{2}\right), 3082(\mathrm{C}-\mathrm{H}),{ }^{1} \mathrm{H}-\mathrm{NMR}$ (400 $\left.\mathrm{MHz}, \mathrm{CDCl}_{3}\right): \delta 3.82\left(\mathrm{~s}, \mathrm{OCH}_{3}, 3 \mathrm{H}\right), 3.84-3.93$ $\left(\mathrm{dd}, 1 \mathrm{H}, \mathrm{H}_{\mathrm{A}}\right), 4.60$ (s, $\left.\mathrm{OCH}_{2}, 2 \mathrm{H}\right), 6.84-6.88$ (dd, 2H, $\left.\mathrm{H}_{\mathrm{B}}, \mathrm{H}_{\mathrm{X}}\right), 7.02-8.37$ (m, Ar-H, 11H). MS (m/z): 427 $(\mathrm{M}+1), 428(\mathrm{M}+2)$.

4-(1-(3-methoxyphenoxy)-3-(thiophen-2-yl)4,5-dihydro-1H-pyrazol-5-yl phenol (3b): IR (KBr) $v\left(\mathrm{~cm}^{-1}\right): 1566(\mathrm{C}=\mathrm{C}), 1602(\mathrm{C}=\mathrm{N}), 1636(\mathrm{C}=\mathrm{O})$, $2881\left(\mathrm{OCH}_{2}\right), 3186(\mathrm{OH}) .{ }^{1} \mathrm{H}-\mathrm{NMR}(400 \mathrm{MHz}$, $\left.\mathrm{CDCl}_{3}\right): \delta 3.70\left(\mathrm{~s}, \mathrm{OCH}_{3}, 3 \mathrm{H}\right), 3.78-3.86(\mathrm{dd}, 1 \mathrm{H}$, $\left.\mathrm{H}_{\mathrm{A}}\right), 4.58\left(\mathrm{~s}, \mathrm{OCH}_{2}, 2 \mathrm{H}\right), 5.09-5.15\left(\mathrm{dd}, 1 \mathrm{H}, \mathrm{H}_{\mathrm{B}}\right)$, 6.49-6.53 (dd, $\left.1 \mathrm{H}, \mathrm{H}_{\mathrm{X}}\right), 6.73-8.01(\mathrm{~m}, \mathrm{Ar}-\mathrm{H}, 1 \mathrm{H})$, 9.50 (s, 1H, OH). MS (m/z): $409(\mathrm{M}+1)$. 5-(4-bromophenyl)-1-(3-methoxyphenoxy)-3(thiophen-2-yl)-4,5-dihydro-1H-pyrazole (3c): IR $(\mathrm{KBr}) v\left(\mathrm{~cm}^{-1}\right): 708(\mathrm{Br}), 1508(\mathrm{C}=\mathrm{C}), 1586(\mathrm{C}=\mathrm{N})$, $1650(\mathrm{C}=\mathrm{O}), 2881\left(\mathrm{OCH}_{2}\right), 3103 \quad(\mathrm{C}-\mathrm{H}) .{ }^{1} \mathrm{H}-\mathrm{NMR}$ $\left(400 \mathrm{MHz}, \mathrm{CDCl}_{3}\right): \delta 2.33\left(\mathrm{~s}, \mathrm{OCH}_{3}, 3 \mathrm{H}\right), 3.27-3.33$ $\left(\mathrm{dd}, 1 \mathrm{H}, \mathrm{H}_{\mathrm{A}}\right), 3.75-3.84\left(\mathrm{dd}, 1 \mathrm{H}, \mathrm{H}_{\mathrm{B}}\right), 4.50\left(\mathrm{~s}, \mathrm{OCH}_{2}\right.$, $2 \mathrm{H})$, 5.83-5.87 (dd, $\left.1 \mathrm{H}, \mathrm{H}_{\mathrm{X}}\right), 6.90-7.70(\mathrm{~m}, \mathrm{Ar}-\mathrm{H}$, 11H). MS (m/z): $472(\mathrm{M}+1)$.

1-(3-methoxyphenoxy)-5-(4-methoxyphenyl)3-(thiophen-2-yl)-4,5-dihydro-1H-pyrazole (3d): IR $(\mathrm{KBr}) v\left(\mathrm{~cm}^{-1}\right): 1569(\mathrm{C}=\mathrm{C}), 1603(\mathrm{C}=\mathrm{N}), 1650$ $(\mathrm{C}=\mathrm{O}), 2882\left(\mathrm{OCH}_{2}\right), 3011(\mathrm{C}-\mathrm{H}) .{ }^{1} \mathrm{H}-\mathrm{NMR}(400$ $\mathrm{MHz}, \mathrm{CDCl}_{3}$ ): $\delta 3.33$ (s, $2 \mathrm{X} \mathrm{OCH}_{3}, 6 \mathrm{H}$ ), 3.79-3.84 $\left(\mathrm{dd}, 1 \mathrm{H}, \mathrm{H}_{\mathrm{A}}\right), 4.57$ (s, $\left.\mathrm{OCH}_{2}, 2 \mathrm{H}\right), 5.83-5.85(\mathrm{dd}, 1 \mathrm{H}$, $\left.\mathrm{H}_{\mathrm{B}}\right)$, 6.58-6.66 (dd, $\left.1 \mathrm{H}, \mathrm{H}_{\mathrm{X}}\right), 6.89-7.82(\mathrm{~m}, \mathrm{Ar}-\mathrm{H}$, $11 \mathrm{H})$. 
Antimicrobial activity. The synthesized pyrazoline derivatives (3a-j) were screened for their antibacterial activity against two gram positive bacterial strains Bacillus subtilis and Staphylococcus aureus and two gram negative bacterial strains Pseudomonas aeruginosa and Escherichia coli as well as antifungal activity against Aspergillus flavus and $A$. fumigatus by using modified Kirby-Bauer disc diffusion method. ${ }^{19}$ All the synthesized compounds were tested at a concentration of $100 \mu \mathrm{gm} / \mathrm{ml}$. The agar medium was incubated with different microorganism cultures tested. The test compounds were dissolved in dimethylformamide (DMF) to prepare the stock solutions. To ensure that the solvent had no effect on bacterial growth, a control test was performed with test medium supplemented with DMF at the same dilutions as used in the experiment. The plates of bacterial culture were incubated at $37^{\circ} \mathrm{C}$ for 18-24 hr and fungal cultures were incubated at $24^{\circ} \mathrm{C}$ for $24-48 \mathrm{hrs}$. The diameter of the zone of inhibition exhibited by the compounds was measured. For each treatment, three replicates were maintained. Ciprofloxacin and flucanazole were used as standard drugs for the comparison of antibacterial and antifungal activities respectively. The antimicrobial activities of the compounds (3a-j) are given in table 3.

Table 3. Antimicrobial activity of 1,3,5-trisubstituted pyrazoline derivatives (3a-j).

\begin{tabular}{lcccccc}
\hline & \multicolumn{5}{c}{ Diameter of zone of inhibition in (mm) [mean \pm S.D (n=3)] } \\
\cline { 2 - 7 } Compd. & B. subtilis & E. coli & P. aeruginosa & S. aureus & A. flavus & A. flumingatus \\
\hline 3a & $16 \pm 4.83$ & $9.33 \pm 2.78$ & $9.33 \pm 2.78$ & $18.66 \pm 5.43$ & $15.66 \pm 4.67$ & $14.66 \pm 4.29$ \\
3b & $7.66 \pm 2.22$ & $8 \pm 2.3$ & $5.33 \pm 1.94$ & $12.33 \pm 3.57$ & $7.66 \pm 2.22$ & $18.66 \pm 5.43$ \\
3c & $12.66 \pm 3.69$ & $13 \pm 3.78$ & $13.66 \pm 4.01$ & $10.66 \pm 3.29$ & $10 \pm 3.21$ & $18 \pm 5.21$ \\
3d & $8 \pm 2.35$ & $8.33 \pm 2.42$ & $17 \pm 4.93$ & $14.33 \pm 4.17$ & $19.66 \pm 5.7$ & $10 \pm 3.03$ \\
3e & $10 \pm 3$ & $8.33 \pm 2.42$ & $12 \pm 3.55$ & $22.33 \pm 6.48$ & $20.33 \pm 5.91$ & $15.33 \pm 4.53$ \\
3f & $13 \pm 3.78$ & $9.66 \pm 2.88$ & $11.33 \pm 3.31$ & $15.66 \pm 4.67$ & $13.33 \pm 3.85$ & $14 \pm 4.06$ \\
3g & $8.33 \pm 2.51$ & $6.33 \pm 2.17$ & $13.66 \pm 3.95$ & $15.33 \pm 4.53$ & $18.33 \pm 5.34$ & $10.33 \pm 3.06$ \\
3h & $10.33 \pm 3.06$ & $11.33 \pm 3.31$ & $9 \pm 2.64$ & $11.33 \pm 3.31$ & $20 \pm 5.94$ & $13.33 \pm 3.91$ \\
3i & $11.33 \pm 3.28$ & $12 \pm 3.55$ & $13.66 \pm 4.06$ & $15.33 \pm 4.48$ & $14 \pm 4.12$ & $13 \pm 3.78$ \\
3j & $11.33 \pm 3.31$ & $8.66 \pm 2.56$ & $11.33 \pm 3.48$ & $13 \pm 3.78$ & $13 \pm 3.84$ & $13.33 \pm 3.91$ \\
Ciprofloxacin & $23 \pm 6.65$ & $25 \pm 7.23$ & $22.33 \pm 6.45$ & $23 \pm 6.68$ & -- & - \\
Fluconazole & -- & -- & -- & - & $25 \pm 7.23$ & $24.33 \pm 7.02$ \\
Control & -- & -- & -- & -- & - & - \\
\hline
\end{tabular}

The antibacterial activity results revealed that all the tested compounds showed weak to moderate activity against $B$. subtilis and $P$. aeruginosa. Some of the tested compounds $\mathbf{3 a}$ and $\mathbf{3 e}$ showed good activity against $S$. aureus. But most of the synthesized compounds displayed very weak activity against E. coli. None of the tested compounds was found to be potent when compared to the standard drug ciprofloxacin.

In the antifungal screening, the tested compounds 3d, 3e, $\mathbf{3 g}$ and $\mathbf{3 h}$ showed good activity against $A$. flavus. Compounds $\mathbf{3 b}$ and $\mathbf{3 c}$ displayed good activity against $A$. fumigatus. The compounds with five membered heterocyclic moiety have displayed good activity against both the fungal organisms. But most of the tested compounds showed moderate activity against both the fungal organisms when compared with standard drug Flucanazole.

\section{RESULTS AND DISCUSSION}

The objective of the present study was to synthesize and investigate the antibacterial and antifungal activities of a new series of pyrazoline derivatives. The reaction sequence is outlined in 
Scheme 01 . The newly synthesized compounds were characterized by various physicochemical parameters (mp, TLC) and also by spectroscopic methods (IR, NMR, mass). Characteristic peaks were observed in FT-IR, NMR and mass spectroscopy. The purity of the compounds was assessed by TLC. The key intermediates chalcones ${ }^{15} \quad(\mathbf{2} \mathbf{a}-\mathbf{j})$ and guanicol hydrazide $^{19}$ (1) were prepared as per the reported procedure. Compounds (3a-j) were synthesized by reacting chalcones and guanicol hydrazide in glacial acetic acid medium. The compounds were obtained in good yields.

\section{Scheme-01}
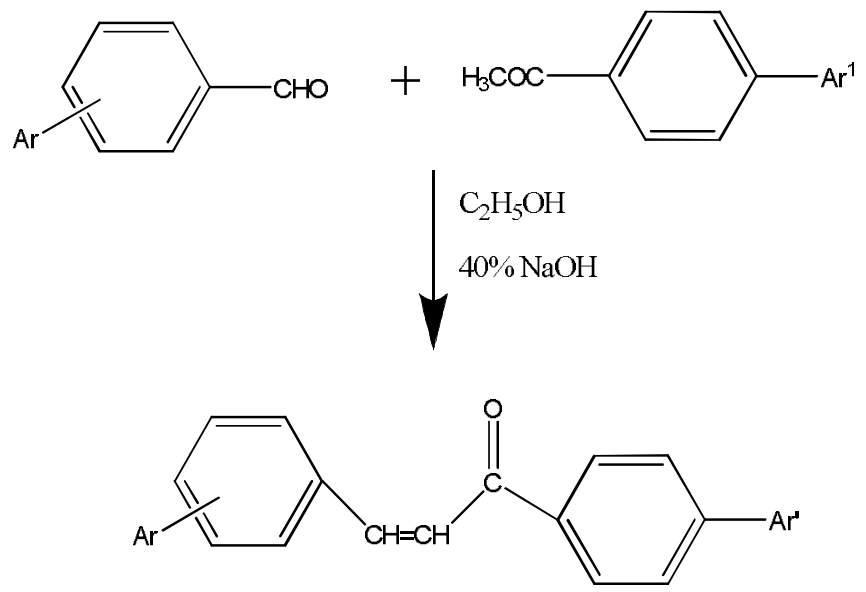

(2a-j)

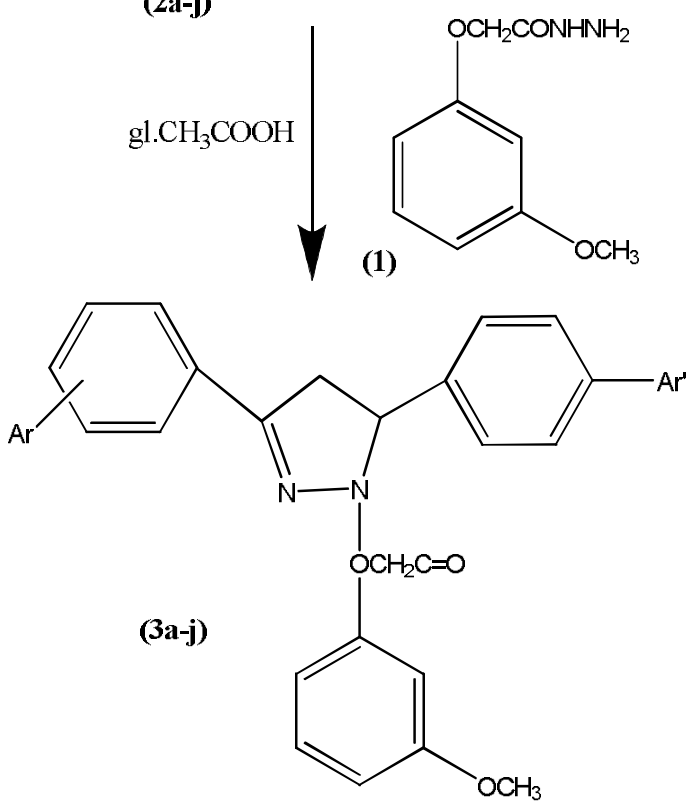

The IR spectra of compounds (3a-j) showed strong absorption bands at frequencies within 28812$2281 \mathrm{~cm}^{-1}$ and $1683-1636 \mathrm{~cm}^{-1}$ due to $\mathrm{OCH}_{2}$ and $\mathrm{C}=\mathrm{O}$ stretching respectively.. The absorption bands observed at 1603-1585 $\mathrm{cm}^{-1}$ was due to $\mathrm{C}=\mathrm{N}$ stretching. In ${ }^{1} \mathrm{H}-\mathrm{NMR}$ spectra, compounds (3a-j) showed doublets of doublets at $\delta$ 3.27-6.88 corresponding to three protons of pyrazoline in $\mathrm{H}_{\mathrm{A}}$, $\mathrm{H}_{\mathrm{B}}, \mathrm{H}_{\mathrm{X}}$ pattern. The methoxy protons was observed in the region at $\delta 2.33-3.82$ and appeared as singlet, integrating for three protons. Aromatic protons resonated as multiplets at $\delta$ 6.73-8.37. Further 
evidence for the formation of pyrazolines (3a-j) was obtained by recording their mass spectra. The mass spectra of the compounds (3a-j) showed a significantly stable molecular ion peak and they were consistent with the molecular formula.

\section{CONCLUSION}

In summary, the paper describes the synthesis of pyrazoline derivatives and their antibacterial activity. The results indicated that most of the synthesized compounds have moderately good inhibitory potential for both bacterial and fungal strains. Among the synthesized pyrazolines, compounds with five membered heterocyclic substituents were found to be more potent in comparison to standard. The synthesized molecules might be helpful for the pharmaceutical industries in drug discovery program.

\section{ACKNOWLEDGEMENTS}

The authors are thankful to authorities of NGSM Institute of Pharmaceutical Sciences, Nitte-deemed to be University, Mangalore for providing all the necessary facilities. The authors are thankful to SAIF, Punjab University, Chandigarh and Oxygen Health Care Research Private Ltd, Ahemedabad for providing spectral data.

\section{REFERENCES}

1. Joule, J.A. and Mills, K. 2000. Heterocyclic Chemistry. Blackwell Science Ltd $4^{\text {th }}$ edn, Germany, Chapter 22, pp.431-445.

2. Jayapal, M.R. and Sreedhar, N.Y. 2011. Synthesis of 2,6dihydroxy substituted chalcones by aldol condensation using $\mathrm{SOCl}_{2}$ /EtOH. Int. J. Pharm. Pharma. Sci. 3, 127-129.

3. Chetana, P., Mahajan, S.K. and Suvarna, A.K. 2009. Chalcone: a versatile molecule. J. Pharm. Sci. Res. 1, 11-22.

4. Karthikeyan, M.S., Holla, B.S. and Kumari, N.S. 2007. Synthesis and antimicrobial studies on novel chloro-fluorine containing hydroxypyrazolines. Eur. J. Med. Chem. 42, 30-36.

5. Herencia, F., Ferrándiz, M.L., Ubeda, A., Domínguez, J.N., Charris, J.E., Lobo, G.M. and Alcaraz, M.J. 1998. Synthesis and anti-inflammatory activity of chalcone derivatives. Bio-org. Med. Chem. Lett. 8, 1169-1174.
6. Jose, N.D., Caritza, L., Juan, R., Jiri, G. and Philip, J.R. 2005. Synthesis and antimalarial activity of sulfonamide chalcone derivatives. Farmacia 60, 307-311.

7. Barsoum, F.F., Hosni, H.M. and Girgis, A.S. 2006. Novel bis(1-acyl-2- pyrazolines) of potential anti-inflammatory and molluscicidal properties. Bio-org. Med. Chem. Lett. 14, 3929-3937.

8. Ozdemir, A., Zitouni, G.T. and Kaplancikli, Z.A. 2008. Novel analogues of 2-pyrazoline: Synthesis, characterization and antimycobacterial evaluation. Turk. J. Chem. 32, 529-538.

9. Korgaokar, S.S., Patil, P.H., Shah, M.J. and Parekh, H.H. 1996. Studies on pyrazolines: preparation and antimicrobial activity of 3-(3'(p-chloro phenyesulphonamidophenyl)-5-aryl1H/acetyl pyrazolines. Ind. J. Pharm. Sci. 58, 222-225.

10. Amir, M., Kumar, H. and Khan, S.A. 2008. Synthesis and pharmacological evaluation of pyrazoline derivatives as new anti-inflammatory and analgesic agents. Bio-org. Med. Chem. Lett. 18, 918-922.

11. Ali, M.A., Siddiqui, A.A. and Shaharyar, M. 2007. Synthesis, structural activity relationship and anti-tubercular activity of novel pyrazoline derivatives. Eur. J. Med. Chem. 42, 268-275.

12. Sharshira, E.M. and Mahrous Hamada, N.M. 2011. Synthesis and in vitro antimicrobial activity of some pyrazolyl-1carboxamide derivatives. Molecules 16, 7736-7745.

13. Prasad, Y.R., Rao, A.L., Prasoona, L., Murali, K. and Kumar, P.R. 2005. Synthesis and antidepressant activity of some 1,3,5-triphenyl-2- pyrazolines and 3-(2H-hydroxynaphthalen111-yl)-1,5-diphenyl-2-pyrazolines. Bio-org. Med. Chem. Lett. 15, 5030-5034

14. Revanasiddappa, B.C., Subrahmanyam, E.V.S. and Lakshmi, T.N. 2011. Synthesis and biological evaluation of pyrazolines. Ind. J. Pharm. Edu. Res. 45, 164-167.

15. Satyanarayana, D., Revanasiddappa, B.C. and Neema, K.V. 2013. Synthesis and biological evaluation of some novel pyrazolines. Ind. J. Het. Chem. 22, 353-356.

16. Revanasiddappa, B.C., Jisha, M.S., Varghese, S.S., Kalsi, J. and Jose N. 2014. Synthesis and biological evaluation of novel 1,3,5-trisubstituted pyrazolines Ind. J. Het. Chem. 24, 51-54.

17. Revanasiddappa, B.C., Vijay Kumar, M., Nayak, P., Ajmal Roshan Ali., Jisha, M.S. 2017. Synthesis, antibacterial and antifungal evaluation of novel pyrazoline derivatives. Res. J. Pharm. Tech. 10, 1481-1484.

18. Mumtaz Md Hussain, Ishwar Bhat K., Revanasiddappa, B.C. and Nataraj, G.R. 2013. Synthesis, antitubercular, antibacterial and antifungal evaluation of novel pyrazoline derivatives. Ind. J. Het. Chem. 22, 267-272.

19. Bauer, A.W., Kirby, W.M., Sherris, J.C. and Turck, M. 1966. Antibiotic susceptibility testing by a standardize single disk method. Am. J. Clin. Pathol. 45, 493-496. 